\title{
Two species of Lumbricillus (Enchytraeidae, Annelida) new to Antarctica
}

\author{
Jeounghee Lee ${ }^{1}$, Mårten Klinth² \& Jongwoo Jung ${ }^{1,3}$ \\ ${ }^{1}$ The Division of EcoCreative, Ewha Woman's University, Seoul, Korea; \\ ${ }^{2}$ Department of Biological and Environmental Sciences, University of Gothenburg, Gothenburg, Sweden; \\ ${ }^{3}$ Department of Science Education, Ewha Woman's University, Seoul, Korea
}

\begin{abstract}
The intertidal fauna of the Antarctic Peninsula has a relatively high species diversity, due to its warmer environment compared to other parts of Antarctica. Marine oligochaetes are, in general, one of the most diverse and ecologically important benthic organism groups, at least in the littoral zone. Antarctica has been one of the least studied areas with regard to oligochaete diversity. Here we report two Lumbricillus species (Lumbricillus antarcticus Stephenson, 1932 and Lumbricillus sejongensis sp. nov.) new to Antarctica, found in a tidal pool on the Barton Peninsula, King George Island. The diversity of this genus remains poorly known for Antarctica and the Subantarctic islands, and what we know is based on a few patchy studies.
\end{abstract}

\begin{abstract}
Keywords
King George Island; Clitellata; Lumbricillus sejongensis sp. nov; Lumbricillus antarcticus; intertidal fauna
\end{abstract}

\section{Correspondence}

Jongwoo Jung, Department of Science

Education, Ewha Womans University, Seoul 03760, Korea. E-mail: jongwoo@ewha.ac.kr

\section{Abbreviations}

KOPRI: Korea Polar Research Institute

\section{Introduction}

Antarctic coastal marine ecosystems are known to be among the most pristine in the world. Benthic organisms in this region are characterized by a higher level of endemism than that on other continents because Antarctica is surrounded by intense currents (such as the Antarctic Circumpolar Current), as well as large bodies of water (Gutt 2001; Barnes et al. 2006; Peck et al. 2006; Rogers 2007; Thornhill et al. 2008).

The Antarctic Peninsula is located in the northernmost part of Antarctica and its coastal region is the warmest and least ice-covered part of the continent. It is home to a wide variety of flora and fauna living in the intertidal zone. Although the distribution of organisms is limited to smaller patches, there is a high diversity of species (Arnaud et al. 1986; Sahade et al. 1998; Bromberg et al. 2000; Quartino et al. 2001; Quartino et al. 2005; Pabis et al. 2011; Siciński et al. 2011).

The intertidal zone of Antarctica is a rapidly changing habitat owing to environmental factors such as sea waves, ice action, salinity change and tidal cycles. Many tidal pools of various sizes near the shoreline are continuously being formed by waves or blizzards. They are fickle habitats whose locations and local conditions-such as temperature, salinity and oxygen content-change with solar exposure, winds and other conditions. Nonetheless, various benthic organisms such as Amphipoda, Copepoda, Crustacea, Gastropoda, Oligochaeta, Polychaeta and Rotifera have been observed in these temporary habitats (Arnaud et al. 1986; Brey \& Clarke 1993; Sahade et al. 1998; Apostolov \& Pandourski 1999; Bromberg et al. 2000; Jazdzewski et al. 2000; Jazdzewski et al. 2001; Lovell \& Trego 2003; Rogers 2007).

Most studies of Antarctic oligochaetes have focused on the marine species (Michaelsen 1888, 1902, 1905a, b, 1914, 1921, 1924; Benham 1915). Thanks to their unique body plan, oligochaete worms are well adapted to benthic and underground environments and are found in a wide range of habitats. Their unique biological adaptations have been an important topic of study, especially their freeze tolerance (Brinkhurst 1980; Didden 1993; Lang \& Reymond 1993; Rodriguez \& Reynoldson 2011; Laurén et al. 2012; Fisker et al. 2014; Rashid \& Pandit 2014; Dial et al. 2016; Herrera et al. 2017). Antarctic oligochaetes have specially adapted themselves to adverse environments. They are good subjects for various biological investigations, all of which are dependent on prior taxonomic research. However, taxonomic studies of Antarctic oligochaetes are rarely undertaken these days.

King George Island is located in the South Shetland Islands, off the north-west tip of the Antarctic Peninsula, and is a site where several studies on the evolution and adaptation of Antarctic organisms have been carried out 
(Brey \& Clarke 1993; Kang et al. 2008; Zhang et al. 2013). To date, 44 species of aquatic oligochaetes have been reported from the Antarctic and Subantarctic (Brinkhurst \& Marchese 1987; Erséus 1994; Rota \& Erséus 1996; Wang \& Liang 1997; Erséus \& Reinmar 2002; Rodriguez \& Rico 2008). From King George Island, only two species have been described-Lumbricillus incisus and Limnodriloides bulbopenitus - in a study more than 20 years ago (Wang \& Liang 1997). Since then, there have been no additional reports about marine oligochaetes from King George Island. In this study, we report two oligochaete species new to Antarctica. They were collected from a tidal pool in Barton Peninsula, the south-western part of King George Island. One of them-Lumbricillus sejongensis sp. nov.-is new to science.

\section{Site description and methods}

The study area is the Barton Peninsula, in the south-western part of King George Island in the South Shetland Islands, Antarctica. It is a small peninsula that is about $10 \mathrm{~km}^{2}(4 \times 3 \mathrm{~km})$ with an average elevation of $150 \mathrm{~m}$, separating Marian Cove and Potter Cove. The strong marine influence makes the climate relatively mild, with mean annual temperatures between $-1.8^{\circ} \mathrm{C}$ and $-1.6^{\circ} \mathrm{C}$. The average relative humidity is $89 \%$ and the precipitation averages $437 \mathrm{~mm}$ (Chung et al. 2004; Kim et al. 2007; Shin et al. 2014). South-western maritime areas of the Barton Peninsula are ice-free during the summer season. Melt and pond waters, which are habitats for aquatic organisms, are concentrated in the coastal area (Lim et al. 2014).

The collection site is on the southern side of the Barton Peninsula $\left(62^{\circ} 13^{\prime} 44.91\right.$ "S, 58 $\left.42^{\prime} 38.62^{\prime \prime W}\right)$ (Fig. 1). It is a tidal pool located between an ice wall and the sea. Sand and gravel containing the specimens were collected from the edge of the pool using a trowel. The material was collected in January 2014 by Dr Sanghee Kim (KOPRI) in connection with an intertidal zone survey from the summer expedition of KOPRI. It was brought to Korea by a participant, Hanna Kim (Ewha Woman's University, Korea), in January 2014.

In the laboratory, the samples were observed and sorted with a Motic SMZ-168 stereo microscope. The worms were fixed in $8 \%$ formalin solution. Taxonomic identification was based on whole-mounted specimen. Fixed whole worms were stained with alcoholic paracarmine, dehydrated in an alcohol series and then mounted in Canada balsam. Photographs were taken with an Olympus DP22 camera system on BX41 research microscope. Length, width and measurements of internal organs were documented based on the mounted material.

The type material of the new species and the specimen of Lumbricillus cf. antarcticus were deposited in the laboratory of Ecological Genetics of Division of EcoCreative, Ewha Woman's University, Seoul, Korea.

\section{Results}

\section{Lumbricillus Ørsted, 1844}

Lumbricillus Ørsted, 1844, p. 68

Pachydrilus (partim) Claparède, 1861, p. 75

Enchytraeus (partim) Ratzel, 1869, p. 856

Lumbricillus Nielsen \& Christensen, 1959, p. 96

Lumbricillus Klinth et al. 2017a, Klinth et al. 2017b

\section{Lumbricillus sejongensis sp. nov.}

(Figs. 2, 3)

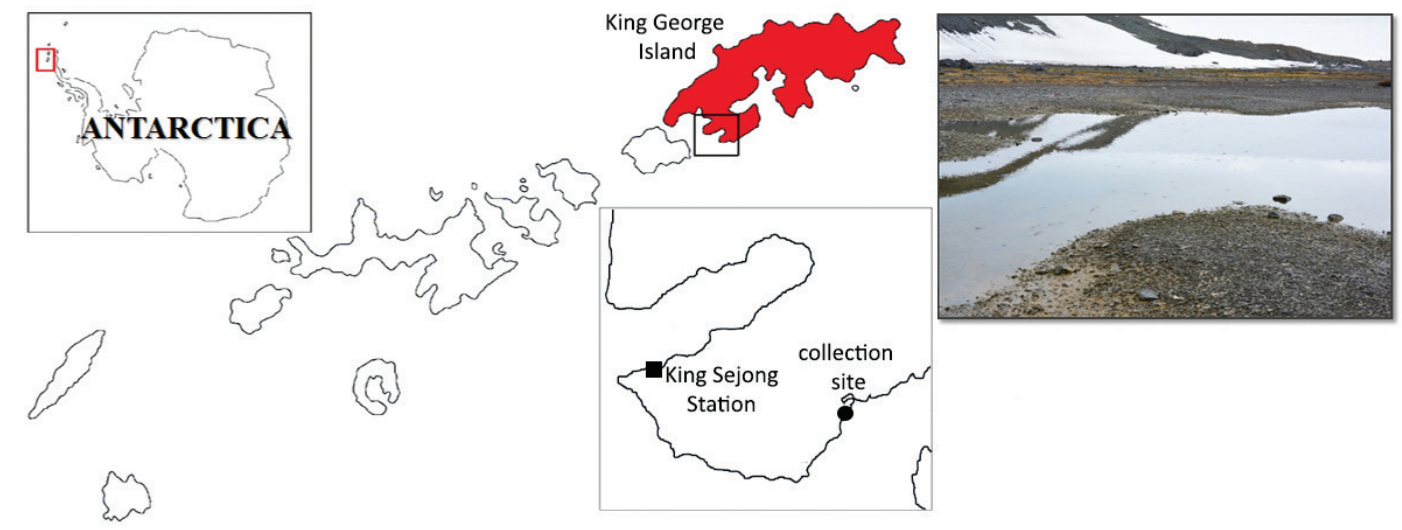

Fig. 1 The collection site in the South Shetland Islands, Antarctica. 



Fig. 2 Lumbricillus sejongensis sp. nov.: (a) anterior part of body; (b) coelomocytes. pg = pharyngeal glands, s = Spermathecae.

Holotype. JHAl40113.1. Mature, complete individual, stainedin alcoholic paracarmine and whole-mounted in Canada Balsam. For the type locality, see the site description above.

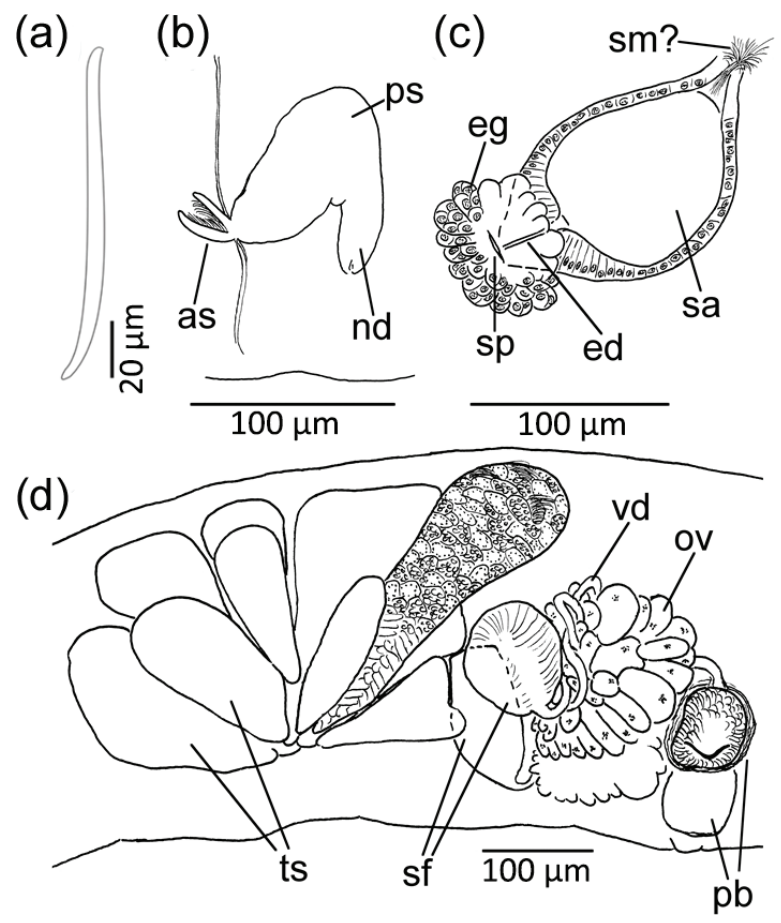

Fig. 3 Lumbricillus sejongensis sp. nov.: (a) chaeta; (b) nephridium; (c) spermatheca; (d) reproductive organs. as = anteseptale, ed = ectal duct of spermatheca, eg = ectal gland at spermathecal pore, $n d=$ nephridial efferent duct, ov = ovary, $\mathrm{pb}=$ penial bulbs, ps = postseptale, $\mathrm{sa}=$ spermathecal ampulla, sf = sperm funnels, $\mathrm{sm}=$ sperm, $\mathrm{sp}=$ spermathecal pore, $\mathrm{ts}=$ testis sacs, $v d=$ vas deferens.
Other material. JHA140113.1. One immature specimen from the type locality (mounted on the same slide as the holotype).

Type locality. The tidal pool located between an ice wall and the sea $\left(62^{\circ} 13^{\prime} 39.44 .91 " \mathrm{~S}, 58^{\circ} 42^{\prime} 38.62^{\prime \prime} \mathrm{W}\right)$, on Barton Peninsula, the south-west end of King George Island, the South Shetland Islands of Antarctica, January 2014.

Description of holotype. Medium-sized species, fixed size about $5.3 \mathrm{~mm}$ long, $0.33 \mathrm{~mm}$ wide at clitellum, with 30 segments. Body smooth. Colour unknown. Epidermis with transverse rows of gland cells. Clitellum extending over XII and 1/2XIII, possibly not fully developed. Chaetae sigmoid, without nodulus. Lateral chaetae: preclitellar 3-4 per bundle $(55-60 \mu \mathrm{m}), 2$ chaetae in XII, postclitellar 2-4 per bundle $(40-60 \mu \mathrm{m})$ (Fig. 3a). Ventral chaetae; preclitellar 4-5 (6) per bundle $(50-60 \mu \mathrm{m})$, missing in XII, postclitellar (2) 3-5 per bundle (45-60 $\mu \mathrm{m})$. Brain fusiform with two short anterior nerve extensions and with posterior incision. Pharyngeal pad in III. Pharyngeal glands in segments IV-VI, as three pairs, with dorsal and ventral lobes, all pairs with dorsal connections (Fig. 2a). With postpharyngeal bulbs. Oesophageal appendages absent. Coelomocytes numerous, oval, round or spindle-shaped, 15-25 $\mu \mathrm{m}$ long, granulated with distinct nucleus (Fig. 2b). Dorsal vessel originating in XII. Nephridia in 7/8-9/10 and 13/14-16/17, about $100 \mu \mathrm{m}$ long, anteseptale consisting of funnel only, postseptale oval, tapering into posteroventral efferent duct (Fig. 3b). Spermathecae in segment V, spindle- or sac-shaped, with short ectal duct made up of cylindrical cells, rapidly widening into large oval ampulla which has a thinner cell 
wall made up of cubical cells, tapering into short ental duct connected to oesophagus. No sperm observed in ampulla but seemingly present in the ental duct communicating with the oesophagus, but this may just be ciliation of the gut. Spermatheca about $170 \mu \mathrm{m}$ long, 90 $\mu \mathrm{m}$ wide at ampulla. Ectal pore encircled by gland cells, forming compact mass, deeply lobed, about $75 \mu \mathrm{m}$ in diameter at its widest part (Fig. 3c). Large testis sacs in X$\mathrm{XI}$, arranged in petal shape with about 10 lobes (Fig. 3d). Sperm funnels in XI, cylindrical, about $130 \mu \mathrm{m}$ long, 60-85 $\mu \mathrm{m}$ wide, making them 1.5-2 times longer than wide (Fig. 3d). Vasa deferentia in XII, irregularly coiled around ovaries, 12-15 $\mu \mathrm{m}$ in diameter. Penial bulbs compact and slightly cubical, glandular mass 45-55 $\mu \mathrm{m}$ in diameter, total diameter (including muscular coating) 60-70 $\mu \mathrm{m}$ (Fig. 3d). Male pores paired, with slight protrusions on ventral side of XII. Ovaries in XII (Fig. 3d). No mature eggs observed. No midventral subneural glands observed but the ventral ganglion is damaged in XIV, which obstructed observation in this segment.

Other material. $3.0 \mathrm{~mm}$ long, $0.23 \mathrm{~mm}$ wide (XII), 25 segments. Lateral preclitellar chaetae 3 per bundle, postclitellar chaetae 2-3 per bundle. Ventral preclitellar chaetae 4-5 per bundle, postclitellar chaetae (2) 3-4 per bundle. With developing sexual organs. Testes seemingly with lobed testis sacs.

Etymology. The species L. sejongensis is named after King Sejong Station, the Korean research station situated near the sampling site of this study.

Remarks. Unfortunately, only a single mature specimen was sampled from this new species. We did find an immature specimen from the same locality, which could belong to the same species but has slightly fewer chaetae than the holotype. What immediately stands out with this new species is the short and stout spermatheca with its large ampulla, which, at first glance, seemed reminiscent of the spermathecae in Lumbricillus pagenstecheri (Ratzel 1869) and the pagenstecheri group (Timm 2005; Klinth et al. 2017b). However, a closer examination revealed a lack of glands along the main part of the ectal duct (there is a ring of glands at the orifice only), therefore making it quite different; the species of the pagenstecheri group has both kinds of glands. The triangular shape of the ectal duct, with its thick cell wall and the rapid widening into the ampulla, together with an abrupt tapering of the ampulla into a short ental duct, gives the spermatheca a spindle-like shape. Another southern Lumbricillus species with a conspicuously thick cell wall in the ectal part of the ampulla is Lumbricillus macquariensis Benham, 1905, described not only from Macquarie Island but also reported from South Georgia Island (Stephenson 1932). This species, however, differs from our new species in having a longer, more set-off, spermathecal ectal duct as well as being much larger (23 $\mathrm{mm}$ in body length). Lumbricillus incisus, described from the same island as our new species, differs in having penial bulbs with a midway constriction and more elongated spermathecae. The species most similar to L. Sejongensis sp. nov. is Lumbricillus healyae Rodriguez \& Rico 2008, described from the not so distant Livingston Island, another island in the South Shetlands. It is slightly larger than our species but has very similar sexual organs. The spermathecae of L. healyae are similar to those of L. incisus and therefore more elongated and with a thicker cell wall also in the ampulla than those of L. sejongensis sp. nov. Furthermore, the dorso-ventral muscular fibres surrounding the penial bulbs in L. healyae were not observed in our specimens, this character should not be mistaken for the muscular coating we described above. Therefore, we conclude that there is no described Lumbricillus species that completely matches our holotype and that it is justifiable to describe this new species despite the limited material.

\section{Lumbricillus cf. Antarcticus Stephenson, 1932 (Fig. 4)}

Lumbricillus antarcticus Stephenson, 1932: pp. 256-257, Fig. 8.

Material. JHAl40113.1-JHAl40113.2. One mature and one half-mature specimen, stained in alcoholic paracarmine and whole-mounted in Canada balsam.

Description. Fixed size $8.2-9.1 \mathrm{~mm}, 44-48$ segments, 0.51-0.56 mm wide at clitellum. Body smooth. Colour unknown. Clitellum extending over XII-1/2XIII. Chaetae sigmoid, without nodulus. Lateral chaetae: preclitellar (3) 4-5 per bundle (60-65 $\mu \mathrm{m}), 2-3$ chaetae in XII, postclitellar 3-6 per bundle $(40-60 \mu \mathrm{m})$. Ventral chaetae: preclitellar 4-7 per bundle $(50-60 \mu \mathrm{m})$, missing in XII, postclitellar (2) 3-8 per bundle $(45-60 \mu \mathrm{m})$. Brain longer than wide, with two narrow anterior nerve extensions and posterior incision (Fig. 4a). Pharyngeal pad in III. Paired pharyngeal glands in segments IV-VI, with dorsal and ventral lobes, all pairs with dorsal connections (Fig. 4c). With postpharyngeal bulbs. Oesophageal appendages absent. Coelomocytes numerous, round, oval or spindle-shaped, $20 \mu \mathrm{m}$ long, with distinct nucleus (Fig. 4b). Dorsal vessel originating in XIII. Nephridia observed in 7/8-9/10, about $210 \mu \mathrm{m}$ long, anteseptale small consisting of funnel only, postseptale longer than high, with posteroventral efferent duct (Fig. 4d). Spermathecae in V, spindle-shaped, with short ectal duct rapidly widening into long ampulla with midway bend, entally connected to oesophagus via an ental duct (Fig. 4e). 

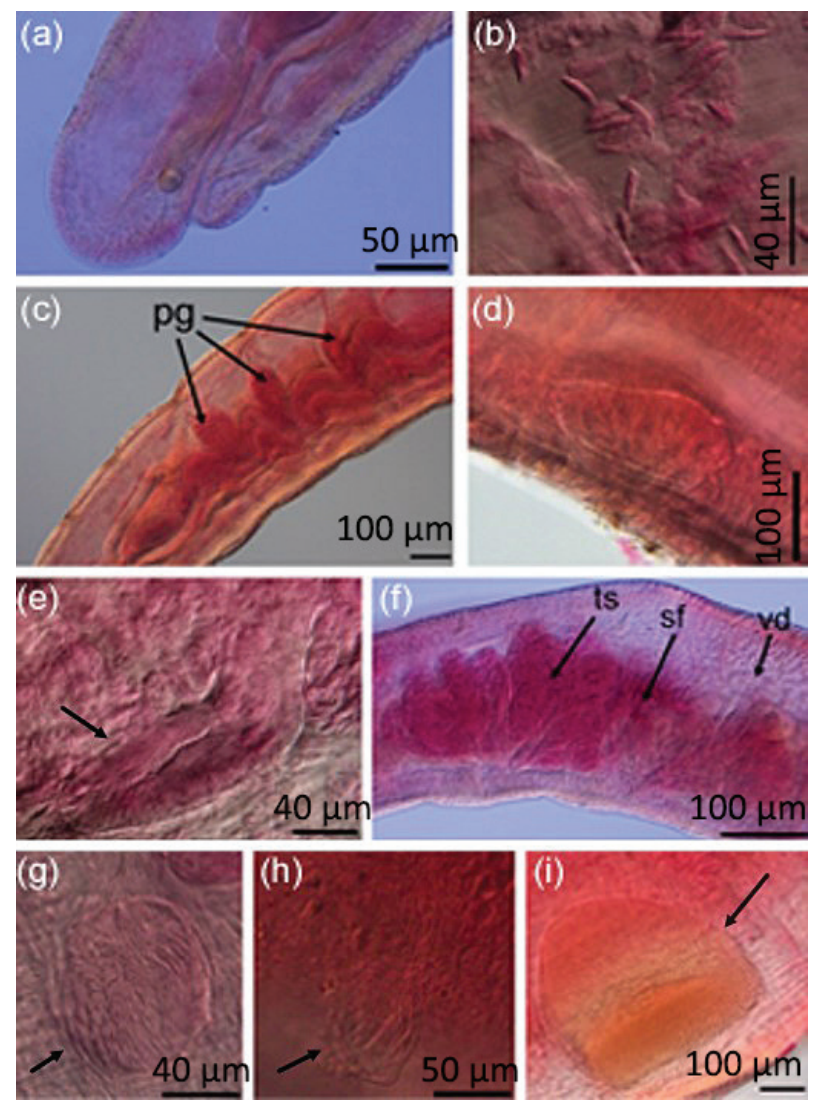

Fig. 4 Lumbricillus cf. Antarcticus Stephenson, 1932: (a) anterior part; (b) coelomocytes; (c) pharyngeal glands; (d) subneural gland; (e) spermathecal ampulla; (f) reproductive organs; (g) penial bulb; (h) penial pore; (i) mature egg.

Sperm filling lumen of ampulla. Spermathecae about 300 $\mu \mathrm{m}$ long and $65 \mu \mathrm{m}$ wide. Ectal pore surrounded by crown of glands, somewhat lobed, about $85 \mu \mathrm{m}$ in diameter. Testis sacs in (IX) X-XI, consisting of about eight club-shaped lobes (Fig. 4f-ts). Sperm funnels in XI, pear-shaped, about $170 \mu \mathrm{m}$ long, $110 \mu \mathrm{m}$ wide, making them 1.5 times longer than wide (Fig. 4f-sf). Vasa deferentia longer than funnel, loosely irregularly coiled in XII, 20-25 $\mu \mathrm{m}$ wide (Fig. 4f-vd). Penial bulbs round, about $85 \mu \mathrm{m}$ in diameter (Fig. $4 \mathrm{~g}, \mathrm{~h}$ ). Ovaries in XII (Fig. 4f-ov). One mature egg observed in one specimen (Fig. 4i). Midventral subneural glands observed in XIII and XIV, 80-110 $\mu \mathrm{m}$ and 85-120 $\mu \mathrm{m}$ long, respectively.

Remarks. Among the Lumbricillus species described from Antarctica, there are a few that are morphologically close to our specimens. Lumbricillus incisus (also from King George Island) is smaller, has fewer chaetae per bundle and penial bulbs with a midway constriction. Lumbricillus healyae (from Livingston Island, also in the South Shetland Islands) is more similar to our specimens with regard to segment number and size of penial bulbs, but it has more chaetae per bundle and shorter spermathecae, where the spermathecal ampulla attaches directly to the oesophagus without tapering into an ental duct. Our two specimens conform rather well with Stephenson's description of L. antarcticus, a species originally described from South Georgia. In particular, the shape of the spermathecae and short sperm funnels are similar to those of Stephenson's species. However, our specimens have more segments, on average more chaetae per bundle and smaller penial bulbs. We lean more towards Stephenson's species, but due to the slight deviations in the morphology we refer to our specimens as L. cf. antarcticus.

\section{Acknowledgements}

The specimens were provided by KOPRI. We are grateful to Dr Sanghee Kim (KOPRI) for collecting the material and Professor Christer Erséus (Gothenburg, Sweden) for his guidance and review of the manuscript. Thanks also to Hanna Kim (Ewha Woman's University, Korea) and Dr Seunghyun Kang (KOPRI) for assistance in collecting material.

\section{Disclosure statement}

The authors report no conflict of interest.

\section{References}

Apostolov A. \& Pandourski I. 1999. Marine harpacticoids (Crustacea: Copepoda) from the littoral of the Livingston Island (the Antarctic). Bulgarian Antarctic Research, Life Sciences 2, 68-82.

Arnaud P.M., Jazdzewski K., Presler P. \& Sicinski J. 1986. Preliminary survey of benthic invertebrates collected by Polish Antarctic Expeditions in Admiralty Bay (King George Island, South Shetland Islands, Antarctica). Polish Polar Research 7, 7-24.

Barnes D.K.A., Linse K., Waller C., Morely S., Enderlein P., Fraser K.P.P. \& Brown M. 2006. Shallow benthic fauna communities of South Georgia Island. Polar Biology 29, 223-228, http://dx.doi.org/10.1007/s00300-005-0042-0.

Benham W.B. 1915. On Lumbricillus macquarensis Benham. Transactions and Proceedings of the New Zealand Institute 47, 189-191.

Brey T. \& Clarke A. 1993. Population dynamics of marine benthic invertebrates in Antarctic and Subantarctic environments-are there unique adaptations? Antarctic Science 5, 253-266, http://dx.doi.org/10.1017/S0954102093000343

Brinkhurst R.O. 1980. Taxonomy, pollution and the sludge worm. Marine Pollution Bulletin 11, 248-251.

Brinkhurst R.O. \& Marchese M.R. 1987. A contribution to the taxonomy of the aquatic Oligochaeta (Haplotaxidae, Phreodrilidae, Tubificidae) of South America. 
Canadian Journal of Zoology 65, 3154-3165, http://dx.doi. org/10.1016/0025-326X(80)90311-2.

Bromberg S., Nonato E.F., Corbisier T.N. \& Petti M.A.V.. 2000. Polychaete distribution in the near-shore zone of Martel Inlet, Admiralty Bay (King George Island, Antarctica). Bulletin of Marine Science 67, 175-188.

Chung H.-S., Lee B.-Y., Chang S.-K., Kim J.-H. \& Kim Y.-D. 2004. Ice cliff retreat and sea-ice formation observed around King Sejong Station in King George Island, West Antarctica. Ocean and Polar Research 26, 1-10, http://dx. doi.org/10.4217/OPR.2004.26.1.001

Claparède R.-É. 1861. Recherches anatomiques sur les annélides, turbellariés, opalines et grégarines observés dans les Hébrides. (Anatomical research on annelids, turbellarians, opalines and gregarines observed in the Hebrides.) Geneva: H. Georg.

Dial R.J., Becker M., Hope A.G., Dial C.R., Thomas J., Slobodenko K.A., Golden T.S. \& Shain D.H. 2016. The role of temperature in the distribution of the glacier ice worm, Mesenchytraeus solifugus (Annelida: Oligochaeta: Enchytraeidae). Arctic, Antarctic, and Alpine Research 48, 199-211, http://dx.doi.org/10.1657/AAAR0015-042.

Didden W. A.M. 1993. Ecology of terrestrial Enchytraeidae. Pedobiologia 37, 2-29.

Erséus C. 1994. Marine Tubificidae (Oligocheata) of Antarctica, with descriptions of three new species of Phallodrilinae. Zoologica Scripta 23, 217-224, http://dx.doi. org/10.1111/j.1463-6409.1994.tb00386.x.

Erséus C. \& Reinmar G. 2002. A new species of Ainudrilus (Tubificidae) from South Georgia, and other Subantarctic freshwater oligochaetes. Hydrobiologia 468, 77-81, http:// dx.doi.org/10.1023/A:1015249024244.

Fisker K.V., Holmstrup M., Malte H. \& JOvergaard J. 2014. Effect of repeated freeze-thaw cycles on geographically different populations of the freeze-tolerant worm Enchytraeus albidus (Oligochaeta). Journal of Experimental Biology 217, 3843-3852, http://dx.doi.org/10.1242/jeb.105650.

Gutt J. 2001. On the direct impact of ice on marine benthic communities, a review. Polar Biology 24, 553-564, http:// dx.doi.org/10.1007/s003000100262.

Herrera L.M., García-Laviña C.X., Marizcurrena J.J., Volonterio O., Ponce de León R. \& Castro-Sowinski S. 2017. Hydrolytic enzyme-producing microbes in the Antarctic oligochaete Grania sp. (Annelida). Polar Biology 40, 947-953, http://dx. doi.org/10.1007/s00300-016-2012-0.

Jazdzewski K., Broyer C., Pudlarz M. \& Zielinski D. 2001. Seasonal fluctuations of vagile benthos in the uppermost sublittoral of a maritime Antarctic fjord. Polar Biology 24, 910-917, http://dx.doi.org/10.1007/s003000100299.

Jazdzewski K., De Broyer C., Pudlarz M. \& Dauby P. 2000. Amphipods of a stony beach in the maritime Antarctic. Polish Archives of Hydrobiology 47, 569-577.

Kang D.-H., Ahn I.-Y. \& Choi K.-S. 2008. The annual reproductive pattern of the Antarctic clam, Laternula elliptica from Marian Cove, King George Island. Polar Biology 32, 517-528, http://dx.doi.org/10.1007/s00300-008-0544-7.

Kim J.H., Ahn I.-Y., Lee K.S., Chung H. \& Choi H.-G. 2007. Vegetation of Barton Peninsula in the neighbourhood of King Sejong Station (King George Island, maritime Antarctic). Polar Biology 30, 903-916, http://dx. doi.org/10.1007/s00300-006-0250-2.

Klinth M.J., Martinsson S. \& Erséus C. 2017a. Phylogeny and species delimitation of North European Lumbricillus (Clitellata, Enchytraeidae). Zoologica Scripta 46, 96-110, http://dx.doi.org/10.1111/zsc.12187.

Klinth M.J., Rota E. \& Erséus C. 2017b. Taxonomy of North European Lumbricillus (Clitellata, Enchytraeidae). Zookeys 703, 15-96, http://dx.doi.org/10.3897/zookeys. 703.13385

Lang C. \& Reymond O. 1993. Recovery of Lake Neuchatel (Switzerland) from eutrophication indicated by the oligochaete communities. Archiv für Hydrobiologie Stuttgart 128, 65-71.

Laurén A., Lappalainen M., Saari P., Kukkonen J.V.K., Koivusalo H., Piirainen S., Setälä H., Sarjala T., Bylund D. \& Heinonen J. 2012. Nitrogen and carbon dynamics and the role of enchytraeid worms in decomposition of L, F and H Layers of boreal mor. Water, Air and Soil Pollution 223, 3701-3719, http://dx. doi.org/10.1007/s11270-012-1142-4.

Lim H.S., Park Y., Lee J.-Y. \& Yoon H.I. 2014. Geochemical characteristics of meltwater and pondwater on Barton and Weaver peninsulas of King George Island, West Antarctica. Geochemical Journal 48, 409-4022, http://dx.doi. $\mathrm{org} / 10.2343 /$ geochemj.2.0316.

Lovell L.L. \& Trego K.D. 2003. The epibenthic megafaunal and benthic infaunal invertebrates of Port Foster, Deception Island (South Shetland Islands, Antarctica). Deep-Sea Research Part II 50, 1799-1819, https://dx.doi.org/10.1016/ S0967-0645(03)00087-0.

Michaelsen W. 1888. Die oligochaeten von Süd-Georgien nach Ausbeute der deutschen station von 1882-83. (The oligochaetes of South Georgia collected at the German station of 1882-83.) Jahrbuch der Hamburgischen Wissenschaftliche Anstalten 5, 53-73.

Michaelsen W. 1902. Die Oligochäten der deutschen Tiefsee-Expedition: nebst Erörterung der Terricolenfauna oceanischer Inseln, insbesondere der Inseln des subarktischen Meeres. (The oligochaetes of the German deep-sea expedition, together with discussion of the terricole fauna of the oceanic islands, in particular in the Subarctic seas.) In C. Chun (ed.): Wissenschaftliche ergebnisse der Deutschen Tiefsee-Expedition auf dem Dampfer "Valdivia" 1898-1899. (Scientific results of the German deep-sea expedition on the steamship Valdivia, 1898-1899.) Pp. 135-166, http://dx.doi.org/10.5962/bhl. title.11698. Jena: Verlag von Gustav Fischer.

Michaelsen W. 1905a. Die Oligochaeten der deutschen Südpolar-Expedition 1901-1903. (The oligochaetes of the German South Polar Expedition 1901-1903.) Deutsche Südpolar-Expedition 1901-1903 9 (Zoologie no. 1), 1-58.

Michaelsen W. 1905b. Die Oligochaten der schwedischen Südpolar-Expedition. (The oligochates of the Swedish South Polar Expedition.) Wissenschaftliche Ergebnisse der Schwedischen Südpolar-Expedition 1901-1903 5 (Zoologie no. 1), 1-12.

Michaelsen W. 1914. Die Oligochaeten des Süsswassers, gesammelt von der Deutschen Südpolar-Expedition. (The freshwater oligochaetes collected by the German South Polar Expedition.) Deutsche Südpolar-Expedition 1901-1903 16 (Zoologie no. 8), 93-97. 
Michaelsen W. 1921. Zur Stammesgeschichte und Systematik der Oligochäten, insbesondere der Lumbriculiden. (The history and systematics of the oligochaetes, in particular the Lumbricidae.) Archiv für Naturgeschichte 8, 130-141.

Michaelsen W. 1924. Papers from Dr. Th. Mortensen's Pacific Expedition 1914-16. XVII. Oligochäten von Neuseeland und den Auckland-Campbell-Inseln, nebst einigen anderen Pacifischen Formen. (Oligochaetes from New Zealand and the Auckland Campbell Islands, along with some other Pacific forms.) Videnskabelige Meddelelser fra Dansk Naturhistorisk Forening i Kobenhavn 75, 197-240.

Nielsen C.O. \& Christensen B. 1959. The Enchytraeidae. Critical revision and taxonomy of European species. Natura Jutlandica Vol. 8-9. Aarhus: Naturhistorisk Museum.

Pabis K., Sicinski J. \& Krymarys M. 2011. Distribution patterns in the biomass of macrozoobenthic communities in Admiralty Bay (King George Island, South Shetlands, Antarctic). Polar Biology 34, 489-500, http://dx.doi. org/10.1007/s00300-010-0903-z.

Peck L.S., Convey P. \& Barnes D.K.A. 2006. Environmental constraints on life histories in Antarctic ecosystems: tempos, timings and predictability. Biological Reviews 81, 75-109, http://dx.doi.org/10.1017/S1464793105006871.

Quartino M., Klöser H., Schloss I. \& Wiencke C. 2001. Biomass and associations of benthic marine macroalgae from the inner Potter Cove (King George Island, Antarctica) related to depth and substrate. Polar Biology 24, 349-355, http://dx.doi.org/10.1007/s003000000218.

Quartino M., Zaixso H.E. \& de Zaixso A.L.B. 2005. Biological and environmental characterization of marine macroalgal assemblages in Potter Cove, South Shetland Islands, Antarctica. Botanica Marina 48, 187-197, http://dx.doi. org/10.1515/BOT2005.029.

Rashid R.\& Pandit A.K. 2014. Macroinvertebrates (oligochaetes) as indicators of pollution: a review. Journal of Ecology and the Natural Environment 6, 140-144, http://dx.doi. org/10.5897/JENE2014.0443.

Ratzel F. 1869. Beiträge zur Anatomie von Enchytraeus vermicularis. (Contributions to the anatomy of Enchytraeus vermicularis.) Zeitschrift für wissenschaftliche Zoologie 18, 563-591.

Rodriguez P. \& Reynoldson T.B. 2011. The pollution biology of aquatic oligochaetes. Dordrecht: Springer.

Rodriguez P. \& Rico E. 2008. A new freshwater oligochaete species (Clitellata: Enchytraeidae) from Livingston Island, Antarctica. Polar Biology 31, 1267-1279, https://doi. org/10.1007/s00300-008-0465-5.
Rogers A.D. 2007. Evolution and biodiversity of Antarctic organisms: a molecular perspective. Philosophical Transactions of the Royal Society B 362, 2191-2214, https://doi. org/10.1098/rstb.2006.1948.

Rota E. \& Erséus C. 1996. Six new species of Grania (Oligochaeta, Enchytraeidae) from the Ross Sea, Antarctica. Antarctic Science 8, 169-183.

Sahade R., Tatián M., Kowalke J., Kühne S. \& Esnal G.B. 1998. Benthic faunal associations on soft substrates at Potter Cove, King George Island, Antarctica. Polar Biology 19, 85-91, http://dx.doi.org/10.1007/s003000050218.

Shin J.-I., Kim H.-C., Kim S.-I. \& Hong S.G. 2014. Vegetation abundance on the Barton Peninsula, Antarctica: estimation from high-resolution satellite images. Polar Biology 37, 1579-1588, http://dx.doi.org/10.1007/ s00300-014-1543-5.

Siciński J., Jażdżewski K., De Broyer C., Presler P., Ligowski R., Nonato E.F., Corbisier T.N., Petti M.A.V., Brito T.A.S., Lavrado H.P., Błażewicz-Paszkowycz M., Pabis K., Jażdżewska A. \& Campos L.S. 2011. Admiralty Bay benthos diversity-a census of a complex polar ecosystem. Deep-Sea Research Part II 58, 30-48, http://dx.doi. org/10.1016/j.dsr2.2010.09.005.

Stephenson J. 1932. Oligochaeta. Part I. Microdrili (mainly Enchytraeidae). In: Discovery reports. Vol. 4. Pp. 233-264, https://doi.org/10.5962/bhl.part.17059. Cambridge: Cambridge University Press.

Thornhill D.J, Mahon A.R., Norenburg J.L. \& Halanych K.M. 2008. Open-ocean barriers to dispersal: a test case with the Antarctic Polar Front and the ribbon worm Parborlasia corrugatus (Nemertea: Lineidae). Molecular Ecology 17, 5104-5117, http://dx.doi. org/10.1111/j.1365-294X.2008.03970.x.

Timm T. 2005. On the distribution and taxonomic limits of Lumbricillus pagenstecheri (Oligochaeta, Enchytraeidae). Proceedings of the Estonian Academy of Sciences, Biology, Ecology 54, 292-301.

Wang H. \& Liang Y. 1997. Two new species of Oligochaeta (Annelida) from King George Island, Antarctica. Oceanologia et Limnologia Sinica 28, 177-184.

Zhang T., Zhang Y.-Q., Liu H.-Y., Wei Y.-Z., Li H.-L., Su J., Zhao L.-X. \& Yu L.-Y. 2013. Diversity and cold adaptation of culturable endophytic fungi from bryophytes in the Fildes Region, King George Island, maritime Antarctica. FEMS Microbiology Letters 341, 52-61, http://dx.doi. org/10.1111/1574-6968.12090. 